\title{
HUBUNGAN FAKTOR MANAJEMEN K3 DENGAN TINDAKAN \\ TIDAK AMAN (UNSAFE ACTION) PADA PEKERJA \\ PT PELABUHAN PENAJAM BANUA TAKA
}

\author{
${ }^{1)}$ Nugroho Dwi Priyohadi \\ ${ }^{2)}$ Arly Achmadiansyah \\ ${ }^{1,2)}$ STIA dan Manajemen Kepelabuhan Barunawati Surabaya \\ ${ }^{1)}$ nugroho.dp@stiamak.ac.id \\ 2) arlyachmadiansyah@gmail.com
}

\begin{abstract}
Abstrak
Tenaga kerja merupakan salah satu komponen terpenting dalam pelaksanaan proyek dan merupakan aset yang menentukan bagi perusahaan. Oleh sebab dalam menjalankan bisnis usaha yang aman, maka penerapan K3 harus dilaksanakan secara konsisten sesuai dengan UU Keselamatan Kerja No.1 Tahun 1970 dan UU Ketenagakerjaan No. 13 Tahun 2003 yang menyatakan bahwa pengusaha wajib melindungi pekerja dan potensi bahaya yang dihadapinya. Kecelakaan industri adalah kejadian kecelakaan yang terjadi di tempat kerja, khususnya di lingkungan industri. Kecelakaan industri secara umum disebabkan oleh 2 (dua) hal pokok yaitu tindakan tidak aman (unsafe action) dan kondisi tidak aman (unsafe condition). Tindakan tidak aman (unsafe action) adalah kegagalan (human failure) dalam mengikuti persyaratan dan prosedur-prosedur kerja yang benar sehingga menyebabkan terjadinya kecelakaan kerja. Tujuan penelitian ini adalah untuk mengetahui pengaruh komitmen dan kebijakan K3, perencanaan K3, pelaksanaan K3, serta pemeriksaan dan tindakan perbaikan K3 terhadap tindakan tidak aman pada pekerja PT. Pelabuhan Penajam Banua Taka. Data yang digunakan dalam penelitian ini adalah data primer yang diperoleh dengan menyebarkan kuesioner kepada karyawan PT. Pelabuhan Penajam Banua Taka berjumlah 50 karyawan. Teknik analisis data menggunakan teknik analisis regresi linier berganda. Hasil penelitian menunjukkan ada pengaruh secara serempak komitmen dan kebijakan $\mathrm{K} 3$, perencanaan $\mathrm{K} 3$, pelaksanaan $\mathrm{K} 3$, serta pemeriksaan dan tindakan perbaikan $\mathrm{K} 3$ terhadap tindakan tidak aman dengan nilai signifikansi masing-masing variabel sebesar sebesar 0,000 kurang dari taraf signifikansi $\alpha=$ 0,05. Selain itu hasil penelitian juga menunjukkan ada pengaruh secara parsial komitmen dan kebijakan K3, perencanaan K3, pelaksanaan K3, serta pemeriksaan dan tindakan perbaikan K3 terhadap tindakan tidak aman.
\end{abstract}

Kata kunci: Komitmen dan Kebijakan K3, Perencanaan K3, Pelaksanaan K3, Pemeriksaan dan Tindakan Perbaikan K3, Tindakan Tidak Aman

\section{PENDAHULUAN}

Tenaga kerja merupakan salah satu komponen terpenting dalam pelaksanaan proyek dan merupakan aset yang menentukan bagi perusahaan. Oleh sebab dalam menjalankan bisnis usaha yang aman, maka penerapan K3 (Keamanan, Keselamatan dan Kesehatan Kerja) harus dilaksanakan secara konsisten, sesuai dengan UU Keselamatan Kerja No.1 Tahun 1970 dan UU Ketenagakerjaan No. 13 Tahun 2003 yang menyatakan bahwa pengusaha wajib melindungi pekerja dan potensi bahaya yang dihadapinya. Kecelakaan industri adalah kejadian kecelakaan yang terjadi di tempat kerja, khususnya di lingkungan industri. Kecelakaan industri secara umum disebabkan oleh 2 (dua) hal pokok yaitu tindakan tidak aman (unsafe action) dan kondisi tidak aman (unsafe condition). Beberapa hasil penelitian menunjukkan bahwa faktor manusia memegang peranan penting timbulnya kecelakaan kerja. Hasil penelitian menyatakan bahwa 80\%- 85\% kecelakaan kerja disebabkan oleh kelalaian atau kesalahan faktor manusia (Depkes RI, 2014).

Tindakan tidak aman (unsafe action) adalah kegagalan (human failure) dalam mengikuti persyaratan dan prosedur-prosedur kerja yang benar sehingga menyebabkan terjadinya kecelakaan kerja, seperti tindakan tanpa kualifikasi dan otoritas, kurang atau tidak menggunakan perlengkapan perlindungan diri, kegagalan dalam menyelamatkan peralatan, bekerja dengan kecepatan yang berbahaya, dan lain sebagainya. Faktor personal, manajemen K3, lingkungan fisik (lingkungan kerja), desain peralatan, pekerjaan, dan sosial/psikologi lingkungan merupakan faktor-faktor yang mempengaruhi terbentuknya tindakan tidak aman (unsafe action). (Winarsunu, 2016).

Dalam menjalankan proses bisnisnya, setiap hari bagian produksi tidak dapat dilepaskan dengan peralatan dan mesin yang memiliki risiko kecelakaan kerja yang tinggi. Berdasarkan hasil wawancara awal dengan perusahaan ada beberapa resiko yang dapat terjadi di perusahaan diantaranya adalah cidera terkena alat potong, cidera terkena alat pemanas, cidera terkena alat setting bahan, cidera terkena peralatan untuk maintenance, cidera terkena komponen yang di cek, cidera terkena komponen yang kurang. Dengan adanya 
keterangan tersebut dan diketahui bahwa mayoritas kecelakaan kerja disebabkan oleh unsafe action, perusahaan disini memiliki concern lebih terhadap pencegahan terjadinya unsafe action pada pekerja. Sehingga diharapkan dengan penelitian ini perusahaan dapat meminimalkan terjadinya kecelakaan kerja yang disebabkan oleh unsafe action.

Berdasarkan data awal tersebut dan diketahui bahwa mayoritas kecelakaan kerja disebabkan oleh unsafe action, perusahaan disini memiliki concern lebih terhadap pencegahan terjadinya unsafe action pada pekerja. Maka diharapkan dengan penelitian ini perusahaan dapat meminimalkan terjadinya kecelakaan kerja yang disebabkan oleh unsafe action. Faktor personal adalah salah satu di antara faktor individual yang mempengaruhi tingkat kecelakaan. Sikap terhadap kondisi kerja, kecelakaan dan praktik kerja yang aman bisa menjadi hal yang penting karena ternyata lebih banyak persoalan yang disebabkan oleh pekerja yang ceroboh dibandingkan dengan mesin-mesin atau karena ketidakpedulian karyawan. Pada satu waktu, pekerja yang tidak puas dengan pekerjaannya dianggap memiliki tingkat kecelakaan kerja yang lebih tinggi. Namun demikian, asumsi ini telah dipertanyakan selama beberapa tahun terakhir. Meskipun kepribadian, sikap karyawan, dan karakteristik individual karyawan tampaknya berpengaruh pada kecelakaan kerja, namun hubungan sebab akibat masih sulit dipastikan. Selain dengan mengetahui lebih lanjut mengenai bagaimana pengaruh faktor tersebut terhadap tindakan tidak aman (unsafe action) penelitian ini untuk melihat adanya hasil hubungan tersebut sehingga perusahaan dapat meminimalkan terjadinya unsafe action pada pekerja. Salah satu cara dalam meminimalkan terjadinya unsafe action pada pekerja adalah dengan mengetahui seberapa seringnya pekerja dalam melakukannya. Tujuan penelitian ini untuk mengetahui pengaruh komitmen dan kebijakan K3, perencanaan K3, pelaksanaan K3, serta pemeriksaan dan tindakan perbaikan K3 terhadap tindakan tidak aman pada pekerja PT. Pelabuhan Penajam Banua Taka.

\section{LANDASAN TEORI DAN PENGEMBANGAN HIPOTESIS}

Kecelakaan kerja merupakan kejadian yang tidak terduga dan tidak diharapkan. Tak terduga, oleh karna itu di belakang peristiwa itu tidak dapat unsur kesengajaan, lebih-lebih dalam bentuk perencanaan. Kecelakaan bisa terjadi akibat kondisi tidak membawa keselamatan kerja, atau perbuatan tidak yang tidak selamat. Jadi, defenisi kecelakaan kerja adalah setiap perbuatan atau kondisi tidak selamat yang dapat mengakibatkan kecelakaan. Kecelakaan kerja merupakan kecelakaan yang berhubungan dengan hubungan kerja pada perusahaan. Hubungan kerja disini dapat berarti, bahwa kecelakaan terjadi dikarenakan oleh pekerjaan atau pada waktu melaksanakan pekerjaan. (Suma'mur, 2015). Kecelakaan menurut Sulaksmono (2016) adalah suatu kejadian tidak diduga dan tidak dikehendaki yang mengacaukan proses suatu aktivitas yang telah diatur. Kecelakaan akibat kerja adalah berhubungan dengan hubungan kerja pada perusahaan. Hubungan kerja disini dapat berarti bahwa kecelakaan terjadi dikarenakan pekerjaan atau pada waktu pekerjaan berlangsung. Silalahi et al., (2015) menyatakan bahwa kecelakaan kerja adalah setiap perbuatan atau kondisi tidak selamat yang dapat mengakibatkan kecelakaan. Adapun pengertian kecelakaan kerja menurut yang lazim berlaku di perusahaanperusahaan Indonesia diartikan sebagai suatu peristiwa atau kejadian yang tidak direncanakan, tidak diharapkan terjadi di perusahaan yang dapat menimbulkan penderitaan bagi pekerja.

Tindakan tidak aman (unsafe action) adalah kegagalan (human failure) dalam mengikuti persyaratan dan prosedur-prosedur kerja yang benar sehingga menyebabkan terjadinya kecelakaan kerja, seperti : tindakan tanpa kualifikasi dan otoritas, kurang atau tidak menggunakan perlengkapan perlindungan diri, kegagalan dalam menyelamatkan peralatan, bekerja dengan kecepatan yang berbahaya, kegagalan pada peringatan, menghindari atau memindahkan peralatan keselamatan kerja, menggunakan peralatan yang tidak layak, menggunakan peralatan tertentu untuk tujuan lain yang menyimpang, bekerja di tempat yang berbahaya tanpa perlindungan dan peringatan yang tepat, memperbaiki peralatan secara salah, bekerja dengan kasar, menggunakan pakaian yang tidak aman ketika bekerja, dan mengambil posisi kerja yang tidak selamat (Winarsunu, 2016).

Tindakan tidak aman adalah tindakan atau perbuatan dari seseorang atau beberapa orang pekerja yang memperbesar kemungkinan terjadinya kecelakaan terhadap pekerja. Tindakan tidak aman yang sering dijumpai, diantaranya adalah: (Suma'mur, 2015)

1. Menjalankan yang bukan tugasnya, gagal memberikan peringatan

2. Menjalankan pesawat lebih dari kecepatan

3. Melepaskan alat pengaman atau membuat alat pengaman tidak berfungsi

4. Menggunakan alat yang rusak

5. Tidak memakai APD

6. Memuat sesuatu secara berlebihan 
7. Menempatkan sesuatu tidak pada tempatnya

8. Mengangkat berlebihan

9. Posisi kerja yang tidak tepat

10. Melakukan perbaikan pada waktu mesin sedang berjalan

11. Bersenda gurau

12. Bertengkar

13. Berada dalam pengaruh obat-obatan ataupun alkohol

Kecelakaan kerja yang terjadi dapat disebabkan oleh beberapa faktor yaitu: (Suma'mur, 2015)

1. Faktor manusia meliputi aturan kerja, kemampuan pekerja (usia, masa kerja/pengalaman, kurangnya kecakapan dan lambatnya mengambil keputusan), disiplin kerja, perbuatan-perbuatan yang mendatangkan kecelakaan, ketidakcocokan fisik dan mental. Kesalahan-kesalahan yang disebabkan oleh pekerja dan karena sikap yang tidak wajar seperti terlalu berani, sembrono, tidak mengindahkan instruksi, kelalaian, melamun, tidak mau bekerja sama, dan kurang sabar. Kekurangan kecakapan untuk mengerjakan sesuatu karena tidak mendapat pelajaran mengenai pekerjaan. Kurang sehat fisik dan mental seperti adanya cacat, kelelahan, dan penyakit.

a. Umur Pekerja

Penelitian dalam test refleks memberikan kesimpulan bahwa umur mempunyai pengaruh penting dalam menimbulkan kecelakaan akibat kerja. Ternyata golongan umur muda mempunyai kecenderungan untuk mendapatkan kecelakaan lebih rendah dibandingkan usia tua, karena mempunyai kecepatan reaksi lebih tinggi. Akan tetapi untuk jenis pekerjaan tertentu sering merupakan golongan pekerja dengan kasus kecelakaan kerja tinggi, mungkin hal ini disebabkan oleh karena kecerobohan atau kelalaian mereka terhadap pekerjaan yang dihadapinya.

b. Pengalaman Bekerja

Pengalaman bekerja sangat ditentukan oleh lamanya seseorang bekerja. Semakin lama dia bekerja maka semakin banyak pengalaman dalam bekerja. Pengalaman kerja juga mempengaruhi terjadinya kecelakaan kerja.

c. Tingkat Pendidikan dan Keterampilan

Pendidikan seseorang mempengaruhi cara berpikir dalam menghadapi pekerjaan, demikian juga dalam menerima latihan kerja baik praktek maupun teori termasuk diantaranya cara pencegahan ataupun cara menghindari terjadinya kecelakaan kerja.

d. Lama Bekerja

Lama bekerja juga mempengaruhi terjadinya kecelakaan kerja. Hal ini didasarkan pada lamanya seseorang bekerja akan mempengaruhi pengalaman kerjanya.

e. Kelelahan

Faktor kelelahan dapat mengakibatkan kecelakaan kerja atau turunnya produktifitas kerja. Kelelahan adalah fenomena kompleks fisiologis maupun psikologis dimana ditandai dengan adanya gejala perasaan lelah dan perubahan fisiologis dalam tubuh. Kelelahan kan berakibat menurunnya kemampuan kerja dan kemampuan tubuh para pekerja.

2. Faktor mekanik dan lingkungan, letak mesin, tidak dilengkapi dengan alat pelindung, alat pelindung tidak pakai, alat-alat kerja yang telah rusak. Lingkungan kerja berpengaruh besar terhadap moral pekerja. Faktorfaktor keadaan lingkungan kerja yang penting dalam kecelakaan kerja terdiri dari pemeliharaan rumah tangga (house keeping), kesalahan disini terletak pada rencana tempat kerja, cara menyimpan bahan baku dan alat kerja tidak pada tempatnya, lantai yang kotor dan licin. Ventilasi yang tidak sempurna sehingga ruangan kerja terdapat debu, keadaan lembab yang tinggi sehingga orang merasa tidak enak kerja. Pencahayaan yang tidak sempurna misalnya ruangan gelap, terdapat kesilauan dan tidak ada pencahayaan setempat.

3. Faktor Pekerjaan

a. Jam Kerja

Jam kerja adalah jam waktu bekerja termasuk waktu istirahat dan lamanya bekerja sehingga dengan adanya waktu istirahat ini dapat mengurangi kecelakaan kerja.

b. Pergeseran Waktu

Pergeseran waktu dari pagi, siang dan malam dapat mempengaruhi terjadinya peningkatan kecelakaan akibat kerja.

Selain itu terdapat pengembangan teori mengenai penyebab kecelakaan kerja (Suma'mur, 2015). Penyebab kecelakaan kerja tersebut berdasarkan sistem manajemen terbagi menjadi unsafe aciton dan unsafe condition. 
Unsafe action merupakan kegagalan (human failure) dalam mengikuti persyaratan dan prosedurprosedur kerja yang benar sehingga menyebabkan terjadinya kecelakaan kerja. Sedangkan unsafe condition kondisi-kondisi yang tidak aman dan berbahaya bagi para pekerja.

Menurut Silalahi (2015), tindakan tidak aman adalah tindakan atau perbuatan dari seseorang atau beberapa orang pekerja yang memperbesar kemungkinan terjadinya kecelakaan terhadap pekerja. Kecelakaan terdiri atas lima faktor yang saling berhubungan :

1. Kondisi kerja

2. Kelalaian manusia

3. Tindakan tidak aman

4. Kecelakaan

5. Cedera

Kelima faktor ini tersusun layaknya kartu domino yang diberdirikan. Jika salah satu jatuh, maka kartu ini akan menimpa kartu lain hingga kelimanya akan roboh secara bersama. Ilustrasi ini mirip dengan efek domino yang telah kita kenal sebelumnya, jika satu bangunan roboh maka kejadian ini akan memicu kejadian beruntun yang menyebabkan runtuhnya bangunan lainnya. Kunci untuk mencegah kecelakaan adalah dengan menghilangkan tindakan tidak aman (poin ketiga dari lima faktor penyebab kecelakaan). Menurut penelitian yang dilakukannya, tindakan tidak aman ini menyumbang $98 \%$ penyebab kecelakaan. Kemudian, bagaimana penjelasan dengan menghilangkan tindakan tidak aman ini dapat mencegah kecelakaan kerja ? kembali lagi ke analogi tindakan tidak aman sebelumnya, jika kartu nomor 3 tidak ada lagi, seandainya kartu nomor 1 dan 2 pun jatuh, ini tidak akan menyebabkan jatuhnya semua kartu. Dengan adanya jarak antara kartu kedua dan keempat, dan jika pun kartu kedua terjatuh, ini tidak akan sampai menimpa kartu nomor 4. Akhirnya kecelakaan nomor 4 dan cidera nomor 5 dapat dicegah. Dengan penjelasan Teori Domino ini, maka kecelakaan kerja dapat dijelaskan dengan logis dan bukan menganggap bahwa kecelakaan kerja akibat bernasib sial ataupun keberuntungan.

Sistem Manajemen K3 merupakan konsep pengelolaan K3 secara sistematis dan komprehensif dalam suatu sistem manajemen yang utuh melalui proses perencanaan, penerapan, pengukuran, dan pengawasan (Ramli, 2010). Sistem manajemen K3 terdiri dari dua unsur pokok yaitu proses manajemen dan elemen-elemen implementasinya. Proses SMK3 menjelaskan bagaimana sistem manajemen tersebut dijalankan atau digerakkan. Sedangkan elemen merupakan komponen-komponen kunci yang terintegrasi satu dengan lainnya membentuk satu kesatuan manajemen. Elemen-elemen ini mencakup antara lain tanggung jawab, wewenang, hubungan antar fungsi, aktivitas, proses, praktis, prosedur dan sumber daya. Elemen ini dipakai untuk menetapkan kebijakan K3, perencanaan, objektif, dan program K3 (Ramli, 2010). Semua sistem manajemen K3 bertujuan untuk mengelola risiko K3 yang ada dalam perusahaan agar kejadian yang tidak diinginkan atau dapat menimbulkan kerugian dapat dicegah. Menurut Dan Petersen dalam bukunya Safety Management, mengelola K3 sama dengan mengelola aspek lain dalam perusahaan dengan menggunakan pendekatan manajemen modern mulai dari perencanaan, pengorganisasian, penerapan dan pengawasan.

Sastrohadiwiryo (2015), menyatakan Sistem Manajemen Keselamatan dan Kesehatan Kerja adalah bagian dari sistem manajemen yang mencakup struktur organisasi, perencanaan, tanggung jawab, pelaksanaan, tata kelola/prosedur, proses dan sumber daya yang dibutuhkan dalam hal pengembangan, penerapan, pencapaian, pengkajian, serta pemeliharaan kebijakan kesehatan dan keselamatan kerja dengan tujuan mengendalikan risiko yang behubungan dengan kegiatan produksi/kerja untuk menciptakan tempat kerja yang aman, efisien dan produktif bagi pekerja maupun orang lain yang berada di dalam lingkungan tersebut. Tujuan dari sistem manajemen K3 adalah menciptakan suatu sistem yang dapat mencegah dan mengurangi kecelakaan serta penyakit yang diakibatkan oleh pekerjaan, menciptakan lingkungan kerja yang aman, efisien, dan produktif, dimana program ini merupakan suatu sistem keselamatan dan kesehatan kerja yang melibatkan unsur manajemen, tenaga kerja, kondisi, dan lingkungan yang terintegrasi.

Berbagai sistem manajemen K3 tersebut dapat digolongkan sebagai berikut :

1. Sebagai ukur kinerja K3 dalam organisasi, SMK3 digunakan untuk menilai dan mengukur kinerja penerapan K3 dalam organisasi. Dengan membandingkan pencapaian K3 organisasi dengan persyaratan tersebut, organisasi dapat mengetahui tingkat pencapaian K3. Pengukuran ini dilakukan melalui audit sistem manajemen K3. Di Indonesia diberlakukan Permenaker No. 05 tahun 1996 tentang audit Sistem Manajemen K3 yang menetapkan kriteria untuk mengukur kinerja K3 perusahaan. 
2. Sebagai pedoman implementasi K3 dalam organisasi, SMK3 sebagai pedoman atau acuan dalam mengembangkan sistem manajemen $\mathrm{K} 3$.

3. Sebagai dasar penghargaan (awards), SMK3 digunakan sebagai dasar untuk pemberian penghargaan $\mathrm{K} 3$ atas pencapaian kinerja $\mathrm{k}$, penghargaan $\mathrm{K} 3$ diberikan oleh instansi pemerintah maupun lembaga independen lainnya seperti Sword of honour dari British Safety Council, Five Star Safety Rating system dari DNV atau National Safety Council Awards, dan SMK3 dari Depnaker. Penghargaan K3 diberikan atas pencapaian kinerja K3 sesuai dengan tolok ukur masing-masing. Karena bersifat penghargaan, maka penilaian hanya berlaku untuk periode tertentu.

4. Sebagai sertifikasi, SMK3 digunakan untuk sertifikasi penerapan manajemen K3 dalam organisasi. Sertifikasi diberikan oleh lembaga sertifikasi yang telah diakreditasi oleh suatu badan akreditasi. Sistem sertifikasi dewasa ini telah berkembang secara global karena dapat diacu di seluruh dunia.

Mengingat banyaknya sistem manajemen K3 yang dikembangkan oleh berbagai institusi tersebut, timbul kebutuhan untuk menstandarisasikan sekaligus memberi sertifikat atas pencapainnya. Disini lahirlah sistem penilaian kinerja K3 yang disebut OHSAS 18000 (Occupational Health And Safety Assessment Series). Sistem ini disertifikasi melalui lembaga sertifikasi, dan diakui secara global. OHSAS 18001 pertama kali diperkenalkan pada tahun 1999 dan kemudian disempurnakan pada tahun 2007 dan disepakati sebagai suatu Standar Sistem Manajemen K3. OHSAS 18000 terdiri dari dua bagian yaitu OHSAS 18001 sebagai standar atau persyaratan SMK3 dan OHSAS 18002 sebagai pedoman pengembangan dan penerapannya (Ramli, 2015).

Budaya keselamatan kerja merupakan salah satu komponen penting dari budaya organisasi yang membahas keselamatan kerja individu, pekerjaan dan halhal yang diutamakan oleh organisasi mengenai keselamatan kerja. Istilah budaya keselamatan (safety culture) pertama kali tertera dalam laporan yang dibuat oleh International Nuclear Safety Advisory Group (INSAG) pada tahun 1987 yang membahas peristiwa Chernoblv. Atas dasar itu, Internasional Atom Energy Agency (IAEA) menyusun konsep atau model dan metode pengukuran Budaya Keselamatan untuk instalasi nuklir, sehingga budaya keselamatan menjadi dikenal secara internasional, khususnya bidang keselamatan dan kesehatan kerja (K3).

Pertama yang diajukan oleh INSAG definisi budaya keselamatan adalah "gabungan dari karakteristik dan sikap dalam organisasi dan individu yang menetapkan bahwa sebagai prioritas utama, masalah keselamatan instalasi nuklir memperoleh perhatian yang sesuai dengan kepentingannya". Pengertian di atas mengkaitkan budaya keselamatan dengan sikap seseorang dan kebiasaannya dengan gaya organisasi. Usulan kedua selanjutnya adalah ternyata bahwa hal tersebut biasanya merupakan sesuatu yang tidak nyata/berwujud; sehingga tidak akan menghasilkan manisfestasi yang nyata/berwujud; dan oleh karena itu persyaratan utama adalah mengembangkan cara-cara untuk menggunakan manisfestasi nyata/berwujud untuk menguji apa yang mendasarinya. INSAG berpendapat bahwa prosedur yang baik dan praktek yang baik tidak memadai bila hanya dilaksanakan secara mekanis. Hal ini mengakibatkan adanya usulan ketiga bahwa budaya keselamatan menuntut semua tugas yang penting untuk keselamatan harus dilaksanakan dengan benar, hati-hati, pemikiran dan pengetahuan penuh dan pengambilan keputusan yang baik dan bertanggung jawab.

Menurut ACSNI budaya keselamatan adalah bagian dari sikap (attitude), keyakinan (belief), dan tata nilai (norm) organisasi pada K3. Budaya keselamatan merupakan sikap dalam organisasi dan individu yang menekankan pentingnya keselamatan. Budaya keselamatan mempersyaratkan agar semua kewajiban yang berkaitan dengan keselamatan harus dilaksanakan secara benar, dan penuh rasa tanggung jawab (Andi, 2017).

Budaya keselamatan kerja menurut Andi (2017) merupakan gabungan nilai-nilai dan kepercayaan-kepercayaan yang berinteraksi dengan struktur organisasi dan sistem pengendalian yang membentuk norma-norma perilaku. Menurut Reason (1997) mengungkap bahwa, budaya keselamatan kerja yang baik dapat membentuk perilaku pekerja terhadap keselamatan kerja yang diwujudkan melalui perilaku aman dalam melakukan pekerjaan. Menurut Andi (2017) budaya keselamatan kerja merupakan kumpulan kepercayaan, norma, sikap, peraturan dan praktek-praktek sosial serta teknis yang ditujukan untuk mengurangi kondisi yang dapat membahayakan pekerja, manajer, pelanggan dan anggota masyarakat. Andi (2017) menyatakan bahwa, budaya keselamatan merupakan interelasi dari tiga elemen, yaitu organisasi, pekerja, dan pekerjaan. Hal ini menunjukkan bahwa budaya keselamatan harus dilaksanakan oleh seluruh sumber daya yang ada, pada seluruh tingkatan dan tidak hanya berlaku untuk pekerja saja. Indikator pelaksanaan budaya keselamatan tergantung dari visi dan misi organisasi. Indikator tersebut tidak dapat ditetapkan dengan paten karena budaya keselamatan suatu hal yang abstrak, dimana di setiap organisasi memiliki budaya yang berbeda. Budaya keselamatan dibentuk oleh komitmen 
manajemen, peraturan dan prosedur, komunikasi, keterlibatan pekerja, kompetensi, dan lingkungan sosial pekerja yang dapat dilihat dari persepsi pekerja (Andi, 2017).

Budaya keselamatan merupakan bagian dari budaya organisasi yang harus memperhitungkan faktor pengambil kebijakan, manajer dan pekerja dalam mewujudkan keselamatan yang terintegrasi. Ada tiga hal yang penting dalam membangun budaya keselamatan. Pertama adanya tata nilai keselamatan; kedua adanya pola perilaku yang sama; ketiga keselamatan adalah tanggung jawab semua orang dalam organisasi. Isi yang muncul adalah cara untuk membentuk budaya keselamatan yang kuat secara berkelanjutan, sehingga keselamatan menjadi tanggung jawab utama atau fokus utama pada seluruh jenis kegiatan.

Menurut Christina (2017) budaya keselamatan berfungsi antara lain:

1. Meminimalkan kemungkinan kecelakaan akibat kesalahan yang dilakukan individu

2. Meningkatkan kesadaran akan bahaya melakukan kesalahan

3. Mendorong pekerja untuk menjalani setiap prosedur dalam semua tahap

4. Mendorong pekerja untuk melaporkan kesalahan / kekurangan sekecil apapun yang terjadi utk menghindari terjadinya kecelakaan.

The Management System for Facilities and Activities Safety Requirements menyatakan bahwa setiap organisasi harus menggunakan sistem manajemen yang digunakan untuk mempromosikan dan mendukung budaya keselamatan dengan cara: (Christina, 2017)

1. Memastikan pemahaman yang sama tentang aspek- aspek kunci budaya keselamatan didalam organisasi.

2. Menyediakan sarana kepada organisasi untuk mendukung tim dan perorangan untuk melaksanakan tugas mereka dengan selamat dan sukses, dengan memperhitungkan interaksi antara perorangan, teknologi dan organisasi.

3. Menekankan sikap bertanya dan belajar pada semua tingkat organisasi.

4. Menyediakan sarana kepada organisasi untuk terus menerus menerapkan, mengembangkan dan memperbaiki budaya keselamatannya.

Penerapan budaya keselamatan dijabarkan menjadi 5 karakteristik budaya keselamatan sebagai berikut: (Christina, 2017)

1. Keselamatan adalah nilai yang diketahui dengan jelas.

2. Kepemimpinan untuk keselamatan adalah jelas.

3. Pertanggungjawaban untuk keselamatan adalah jelas

4. Keselamatan merupakan penggerak pembelajaran

5. Keselamatan terintegrasi pada semua aktivitas.

Berdasarkan kajian teori dan fenomena persoalan di lapangan maka hipotesis dalam penelitian ini adalah:

H1: Komitmen dan kebijakan K3 mempunyai pengaruh terhadap tindakan tidak aman

$\mathrm{H} 2$ : Perencanaan K3 mempunyai pengaruh terhadap tindakan tidak aman

$\mathrm{H} 3$ : Pelaksanaan K3 mempunyai pengaruh terhadap tindakan tidak aman

$\mathrm{H} 4$ : Pemeriksaan dan tindakan perbaikan K3 mempunyai pengaruh terhadap tindakan tidak aman

\section{METODOLOGI PENELITIAN}

Variabel dalam penelitian ini meliputi:

1. Variabel bebas (independent variable)

Variabel bebas $(\mathrm{X})$ yaitu variabel yang nilainya mempengaruhi nilai variabel lain, atau variabel yang menjadi sebab timbulnya atau berubahnya variabel dependent / variabel terikat (Sugiyono, 2015: 52). Dalam penelitian ini yang termasuk dalam variabel bebas adalah :

a. Komitmen dan kebijakan $\mathrm{K} 3\left(\mathrm{X}_{1}\right)$, meliputi:

1) Manajemen perusahaan bertanggungjawab terhadap kinerja $K 3$

2) Manajemen perusahaan menyediakan tenaga kerja berkualitas dan sarana-sarana yang diperlukan di bidang $\mathrm{K} 3$

3) Perencanaan $\mathrm{K} 3$ terkoordinasi dengan baik

4) Perusahaan melakukan penilaian tindaklanjut pelaksanaan K3

5) Kebijakan $\mathrm{K} 3$ dikonsultasikan dengan tenaga kerja

b. Perencanaan $\mathrm{K} 3\left(\mathrm{X}_{2}\right)$, meliputi: 
1) Perencanaan kerja dilakukan dengan mempertimbangkan identifikasi bahaya, penilaian dan pengendalian risiko pada kegiatan yang akan dilakukan

2) Perusahaan melakukan pengujian lingkungan kerja secara berkala setiap tahun

3) Prosedur kerja telah disosialisasikan seluruh pekerja

4) Prosedur menghadapi keadaan darurat dan bencana alam

5) Prosedur menghadapi insiden yang meliputi penyediaan fasilitas P3K dengan jumlah yang cukup dan sesuai sampai mendapatkan pertolongan medik, dan proses perawatan lanjutan.

c. Pelaksanaan K3 $\left(\mathrm{X}_{3}\right)$, meliputi:

1) Pemeriksaan kesehatan pekerja secara berkala setiap tahun.

2) Rambu-rambu mengenai keselamatan dan tanda pintu darurat telah dipasang dengan jelas.

3) Pekerja diberi arahan tentang bagaimana menggunakan APD secara benar dan memelihara APD sehingga selalu dalam kondisi layak pakai.

4) Alat pelindung diri yang berkualitas telah disediakan.

5) Pekerja selalu diberi arahan tentang bagaimana mengindentifikasi bahaya yang mengancam pada saat bekerja dan bagaimana mencegah terjadinya insiden.

d. Pemeriksaan dan tindakan perbaikan $\mathrm{K} 3\left(\mathrm{X}_{4}\right)$, meliputi:

1) Pengawasan yang dilakukan petugas berwenang untuk menjamin pekerjaan dilaksanakan secara aman dan mengikuti setiap prosedur kerja yang telah ditetapkan.

2) Catatan inspeksi, pengujian dan pemantauan terpelihara dengan baik

3) Adanya pelaporan informasi yang terkait dengan identifikasi sumber bahaya, kinerja K3, kecelakaan kerja.

4) Mengawasi pelaksanaan pekerjaan sesuai dengan SOP pelaksanaan program K3.

5) Perbaikan dan pencegahan dilaksanakan berdasarkan hasil temuan.

\section{Variabel terikat (dependent variable)}

Variabel terikat (Y) yaitu variabel yang dipengaruhi atau menjadi akibat karena adanya variabel bebas (Sugiyono, 2015: 52). Dalam penelitian ini yang termasuk dalam variabel terikat adalah tindakan tidak aman. Tindakan tidak aman (Y) adalah tindakan atau perbuatan dari seseorang atau beberapa orang pekerja yang memperbesar kemungkinan terjadinya kecelakaan kerja, meliputi:

a. Menjalankan peralatan atau mesin kerja tanpa perintah atau wewenang

b. Menjalankan peralatan atau mesin kerja dengan kecepatan yang tidak sesuai prosedur

c. Membuat alat pengaman pada mesin menjadi tidak berfungsi

d. Menghilangkan atau memindahkan pengaman

e. Menggunakan peralatan kerja yang tidak sesuai dengan pekerjaannya

Populasi dalam penelitian ini adalah karyawan operasional di lapangan yang berkaitan langsung dengan progran Kesehatan dan Keselamatan Kerja (K3) PT. Pelabuhan Penajam Banua Taka sebanyak 50 orang. Sampel yang dipergunakan adalah seluruh karyawan PT. Pelabuhan Penajam Banua Taka. Penelitian ini menggunakan teknik sensus yaitu semua populasi diteliti (Sugiyono, 2015: 78). Semua populasi 50 pegawai dijadikan sampel.

Analisis data meliputi:

1. Uji validitas dan reliabitas

Uji validitas dan reliabilitas digunakan untuk analisis butir item kuesioner. Suatu kuesioner dinyatakan valid jika nilai probabilitas setiap item dari variabel lebih kecil dari taraf signifikansi ( $\square$ ) 0,05 dan suatu konstruk atau variabel dikatakan reliabel bila nilai alpha Cronbach > 0,6.

2. Analisis regresi linier berganda

Analisis yang digunakan pada penelitian ini adalah regresi linier berganda. Uji t untuk uji secara parsial dan uji F untuk uji secara simultan. Rumus tersebut adalah sebagai berikut:

Rumus Regresi Berganda :

$Y=\beta o+\beta_{1} X_{1}+\beta_{2} X_{2}+\beta_{3} X_{3}+\beta_{4} X_{4}+e$

Keterangan :

$\mathrm{Y}=$ tindakan tidak aman

$\mathrm{X}_{1}=$ komitmen dan kebijakan K3

$\mathrm{X}_{2} \quad=\quad$ perencanaan $\mathrm{K} 3$ 


$\begin{array}{lll}\mathrm{X}_{3} & = & \text { pelaksanaan } \mathrm{K} 3 \\ \mathrm{X}_{4} & = & \text { pemeriksaan dan tindakan perbaikan } \mathrm{K} 3 \\ \beta \mathrm{O} & = & \text { konstanta } \\ \beta_{1 \ldots . . .} \beta_{3} & = & \text { koefisien regresi } \\ \mathrm{e} & = & \text { variabel pengganggu di luar variabel bebas }\end{array}$

\section{HASIL PENELITIAN}

\section{Uji Validitas Data}

Hasil uji validitas dan reliabilitas sebagai berikut:

1. Uji Validitas Komitmen dan Kebijakan K3

Tabel 1

Uji Validitas Komitmen dan Kebijakan K3 (X1)

\begin{tabular}{|c|c|c|c|}
\hline Indikator & Korelasi & Signifikan & Keterangan \\
\hline X1.1 & 0,649 & 0,000 & Valid \\
X1.2 & 0,703 & 0,000 & Valid \\
X1.3 & 0,521 & 0,000 & Valid \\
X1.4 & 0,648 & 0,000 & Valid \\
X1.5 & 0,532 & 0,000 & Valid \\
\hline
\end{tabular}

Berdasarkan tabel di atas, diketahui bahwa nilai probabilitas kelima item pembentuk komitmen dan kebijakan K3 lebih kecil dari taraf signifikansi $(\alpha)$ 0,05, berarti kelima item tersebut valid (Ghozali, 2015 : 137).

2. Uji Validitas Perencanaan K3

Tabel 2

Uji Validitas Perencanaan K3 (X2)

\begin{tabular}{|c|c|c|c|}
\hline Indikator & Korelasi & Signifikan & Keterangan \\
\hline X2.1 & 0,740 & 0,000 & Valid \\
X2.2 & 0,507 & 0,000 & Valid \\
X2.3 & 0,636 & 0,000 & Valid \\
X2.4 & 0,510 & 0,000 & Valid \\
X2.5 & 0,643 & 0,000 & Valid \\
\hline
\end{tabular}

Berdasarkan tabel di atas, diketahui bahwa nilai probabilitas kelima item pembentuk perencanaan K3 lebih kecil dari taraf signifikansi $(\alpha)$ 0,05, berarti kelima item tersebut valid (Ghozali, 2015: 137).

3. Uji Validitas Pelaksanaan K3

Tabel 3

Uji Validitas Pelaksanaan K3 (X3)

\begin{tabular}{|c|c|c|c|}
\hline Indikator & Korelasi & Signifikan & Keterangan \\
\hline X3.1 & 0,739 & 0,000 & Valid \\
X3.2 & 0,644 & 0,000 & Valid \\
X3.3 & 0,611 & 0,000 & Valid \\
X3.4 & 0,523 & 0,000 & Valid \\
X3.5 & 0,597 & 0,000 & Valid \\
\hline
\end{tabular}

Berdasarkan tabel di atas, diketahui bahwa nilai probabilitas kelima item pembentuk pelaksanaan K3 lebih kecil dari taraf signifikansi $(\alpha)$ 0,05, berarti kelima item tersebut valid (Ghozali, 2015: 137).

4. Uji Validitas Pemeriksaan dan Tindakan Perbaikan K3

Tabel 4

Uji Validitas Pemeriksaan dan Tindakan Perbaikan K3 (X4)

\begin{tabular}{|c|c|c|c|}
\hline Indikator & Korelasi & Signifikan & Keterangan \\
\hline X4.1 & 0,565 & 0,000 & Valid \\
X4.2 & 0,650 & 0,000 & Valid \\
X4.3 & 0,624 & 0,000 & Valid \\
X4.4 & 0,778 & 0,000 & Valid \\
X4.5 & 0,691 & 0,000 & Valid \\
\hline
\end{tabular}

Berdasarkan tabel di atas, diketahui bahwa nilai probabilitas kelima item pembentuk pemeriksaan dan tindakan perbaikan K3 lebih kecil dari taraf signifikansi $(\alpha) 0,05$, berarti kelima item tersebut valid (Ghozali, 2015: 137).

5. Uji Validitas Tindakan Tidak Aman 
Uji Validitas Tindakan Tidak Aman (Y)

\begin{tabular}{|c|c|c|c|}
\hline Indikator & Korelasi & Signifikan & Keterangan \\
\hline Y.1 & 0,648 & 0,000 & Valid \\
Y.2 & 0,715 & 0,000 & Valid \\
Y.3 & 0,791 & 0,000 & Valid \\
Y.4 & 0,653 & 0,000 & Valid \\
Y.5 & 0,664 & 0,000 & Valid \\
\hline
\end{tabular}

Berdasarkan tabel di atas, diketahui bahwa nilai probabilitas kelima item pembentuk tindakan tidak aman lebih kecil dari taraf signifikansi $(\alpha)$ 0,05, berarti kelima item tersebut valid (Ghozali, 2015: 137).

Uji reliabilitas dimaksudkan untuk melihat tingkat kehandalan instrumen sebagai alat ukur dalam penelitian, sehingga hasil penelitian nantinya benar-benar memenuhi standar ilmiah dan tidak bias. Untuk menguji reliabilitas instrumen ini menggunakan koefisien reliabilitas Cronbach's Alpha, hasil selengkapnya dapat dilihat pada tabel di bawah:

Tabel 6. Hasil Uji Reliabilitas

\begin{tabular}{|l|c|c|}
\hline \multicolumn{1}{|c|}{ Variabel } & Alpha Cronbach & Keterangan \\
\hline komitmen dan kebijakan K3 (X1) & 0,674 & Reliabel \\
\hline perencanaan K3 (X2) & 0,642 & Reliabel \\
\hline pelaksanaan K3 (X3) & 0,606 & Reliabel \\
\hline pemeriksaan dan tindakan perbaikan K3 (X4) & 0,622 & Reliabel \\
\hline tindakan tidak aman (Y) & 0,715 & Reliabel \\
\hline
\end{tabular}

Berdasarkan tabel 5, dapat dijelaskan sebagai berikut:

1. Nilai reliabilitas komitmen dan kebijakan K3 sebesar 0,674 sudah reliabel karena lebih besar dari 0,60 (Ghozali, 2015: 133).

2. Nilai reliabilitas perencanaan K3 sebesar 0,642 sudah reliabel karena lebih besar dari 0,60 (Ghozali, 2015: 133).

3. Nilai reliabilitas pelaksanaan K3 sebesar 0,606 sudah reliabel karena lebih besar dari 0,60 (Ghozali, 2015: 133).

4. Nilai reliabilitas pemeriksaan dan tindakan perbaikan K3 sebesar 0,622 sudah reliabel karena lebih besar dari 0,60 (Ghozali, $2015: 133$ ).

5. Nilai reliabilitas tindakan tidak aman sebesar 0,715 sudah reliabel karena lebih besar dari 0,60 (Ghozali, 2015: 133).

\section{Uji Regresi Linier Berganda}

Hasil perhitungan dalam analisis menggunakan program SPSS for Windows release 22.0 seperti yang tercantum pada lampiran, lebih rinci dapat dijelaskan sebagai berikut:

Tabel 7. Koefisien Regresi

\begin{tabular}{|l|c|}
\hline \multicolumn{1}{|c|}{ Variabel } & Koefisien Regresi \\
\hline Konstanta & 1,266 \\
\hline Komitmen dan kebijakan K3 (X1) & 0,132 \\
\hline Perencanaan K3 (X2) & 0,130 \\
\hline Pelaksanaan K3 (X3) & 0,144 \\
\hline Pemeriksaan dan tindakan perbaikan K3 (X4) & 0,326 \\
\hline
\end{tabular}

Persamaan regresi linier berganda akan diperoleh sebagai berikut :

$Y=\beta_{0}+\beta_{1} X_{1}+\beta_{2} X_{2}+\beta_{3} X_{3}+\beta_{4} X_{4}+e$

$Y=1,266+0,132 X_{1}+0,130 X_{2}+0,144 X_{3}+0,326 X_{4}$

Dari persamaan tersebut diatas dapat dijelaskan sebagai berikut:

1. Konstanta $\left(\beta_{0}\right)$ sebesar 1,266 menunjukkan besarnya tindakan tidak aman, apabila seluruh variabel bebas tersebut sama dengan nol.

2. Koefisien regresi untuk komitmen dan kebijakan $\mathrm{K} 3\left(\mathrm{X}_{1}\right)$ sebesar 0,132 . Berarti jika komitmen dan kebijakan $\mathrm{K} 3\left(\mathrm{X}_{1}\right)$ naik sebesar 1 satuan, maka tindakan tidak aman $(\mathrm{Y})$ akan mengalami kenaikan sebesar 0,132 satuan. 
3. Koefisien regresi untuk perencanaan $\mathrm{K} 3\left(\mathrm{X}_{2}\right)$ sebesar 0,130. Berarti jika perencanaan $\mathrm{K} 3\left(\mathrm{X}_{2}\right)$ naik sebesar 1 satuan, maka tindakan tidak aman (Y) akan mengalami kenaikan sebesar 0,130 satuan.

4. Koefisien regresi untuk pelaksanaan $\mathrm{K} 3\left(\mathrm{X}_{3}\right)$ sebesar 0,144. Berarti jika pelaksanaan $\mathrm{K} 3\left(\mathrm{X}_{3}\right)$ naik sebesar 1 satuan, maka tindakan tidak aman (Y) akan mengalami kenaikan sebesar 0,144 satuan.

5. Koefisien regresi untuk pemeriksaan dan tindakan perbaikan $\mathrm{K} 3\left(\mathrm{X}_{4}\right)$ sebesar 0,326. Berarti jika pemeriksaan dan tindakan perbaikan $\mathrm{K} 3\left(\mathrm{X}_{4}\right)$ naik sebesar 1 satuan, maka tindakan tidak aman $(\mathrm{Y})$ akan mengalami kenaikan sebesar 0,326 satuan.

Nilai adjusted $R$ square dimana hasil perhitungan dari lampiran 3 sebesar 0,617 atau 61,7\% pengaruh komitmen, komunikasi dan pengawasan terhadap tindakan tidak aman sebesar $61,7 \%$, sisanya $39,3 \%$ dipengaruhi oleh variabel lain yang tidak terdapat dalam model. Hasil uji t pada penelitian ini disajikan pada tabel 8.

Tabel 8. Hasil Uji t

\begin{tabular}{|l|c|c|c|l|}
\hline \multicolumn{1}{|c|}{ Variabel } & t hitung & t tabel & Signifikan & Keterangan \\
\hline Komitmen dan kebijakan K3 (X1) & 5,631 & 2,014 & 0,000 & Ada pengaruh \\
\hline Perencanaan K3 (X2) & 4,747 & 2,014 & 0,000 & Ada pengaruh \\
\hline Pelaksanaan K3 (X3) & 6,622 & 2,014 & 0,000 & Ada pengaruh \\
\hline $\begin{array}{l}\text { Pemeriksaan dan tindakan perbaikan } \\
\text { K3 (X4) }\end{array}$ & 7,683 & 2,014 & 0,000 & Ada pengaruh \\
\hline
\end{tabular}

Hasil uji t pada tabel 7 dapat dijelaskan sebagai berikut

1. Nilai t hitung komitmen dan kebijakan K3 (X1) sebesar 5,631 lebih besar dari t tabel 2,014 menunjukkan bahwa komitmen dan kebijakan K3 berpengaruh terhadap tindakan tidak aman. Hipotesis pertama (H1) yang menyatakan komitmen dan kebijakan K3 berpengaruh terhadap tindakan tidak aman diterima.

2. Nilai t hitung perencanaan K3 (X2) sebesar 4,747 lebih besar dari t tabel 2,014 menunjukkan bahwa perencanaan K3 berpengaruh terhadap tindakan tidak aman. Hipotesis kedua (H2) yang menyatakan perencanaan $\mathrm{K} 3$ berpengaruh terhadap tindakan tidak aman diterima.

3. Nilai t hitung pelaksanaan K3 (X3) sebesar 6,622 lebih besar dari t tabel 2,014 menunjukkan bahwa pelaksanaan K3 berpengaruh terhadap tindakan tidak aman. Hipotesis ketiga (H3) yang menyatakan pelaksanaan K3 berpengaruh terhadap tindakan tidak aman diterima.

4. Nilai t hitung pemeriksaan dan tindakan perbaikan K3 (X4) sebesar 7,683 lebih besar dari t tabel 2,014 menunjukkan bahwa pemeriksaan dan tindakan perbaikan K3 berpengaruh terhadap tindakan tidak aman. Hipotesis keempat (H4) yang menyatakan pemeriksaan dan tindakan perbaikan K3 berpengaruh terhadap tindakan tidak aman diterima.

\section{PEMBAHASAN}

Pengaruh Komitmen dan Kebijakan K3, Perencanaan K3, Pelaksanaan K3, serta Pemeriksaan dan Tindakan Perbaikan K3 Terhadap Tindakan tidak aman

Nilai koefisien determinasi (adjusted $R$ Square) yaitu sebesar 0,617, ini menunjukkan bahwa besarnya kontribusi antara variabel bebas yaitu komitmen dan kebijakan $\mathrm{K} 3\left(\mathrm{X}_{1}\right)$, perencanaan $\mathrm{K} 3\left(\mathrm{X}_{2}\right)$, pelaksanaan K3 $\left(\mathrm{X}_{3}\right)$, serta pemeriksaan dan tindakan perbaikan $\mathrm{K} 3\left(\mathrm{X}_{4}\right)$ secara simultan menjelaskan perubahan variasi dari variabel terikat tindakan tidak aman (Y) sebesar 61,7\% sedangkan sisanya sebesar 38,3\% dijelaskan oleh variabel lain.

\section{Pengaruh Komitmen dan Kebijakan K3 Terhadap Tindakan Tidak Aman}

Hasil perhitungan menunjukkan nilai signfikansi komitmen dan kebijakan K3 sebesar 0,000 < taraf signifikansi $\alpha=0,05$, sehingga dapat disimpulkan bahwa komitmen dan kebijakan $\mathrm{K} 3\left(\mathrm{X}_{1}\right)$ berpengaruh terhadap tindakan tidak aman. Hipotesis yang menyatakan bahwa komitmen dan kebijakan K3 berpengaruh secara parsial terhadap tindakan tidak aman PT. Pelabuhan Penajam Banua Taka diterima.

\section{Pengaruh Perencanaan K3 Terhadap Tindakan Tidak Aman}

Hasil perhitungan menunjukkan nilai signfikansi perencanaan K3 sebesar $0,000<$ taraf signifikansi $\alpha=0,05$, sehingga dapat disimpulkan bahwa perencanaan $\mathrm{K} 3\left(\mathrm{X}_{2}\right)$ berpengaruh signifikan terhadap tindakan tidak aman. Hipotesis yang menyatakan bahwa perencanaan K3 berpengaruh secara parsial terhadap tindakan tidak aman PT. Pelabuhan Penajam Banua Taka diterima.

\section{Pengaruh Pelaksanaan K3 Terhadap Tindakan Tidak Aman}

Hasil perhitungan menunjukkan nilai signfikansi pelaksanaan $\mathrm{K} 3$ sebesar $0,000<$ taraf signifikansi $\alpha=0,05$, sehingga dapat disimpulkan bahwa pelaksanaan $\mathrm{K} 3\left(\mathrm{X}_{3}\right)$ berpengaruh signifikan terhadap tindakan tidak aman. 
Hipotesis yang menyatakan bahwa pelaksanaan K3 berpengaruh secara parsial terhadap tindakan tidak aman PT. Pelabuhan Penajam Banua Taka diterima.

\section{Pengaruh Pemeriksaan dan Tindakan Perbaikan K3 Terhadap Tindakan Tidak Aman}

Hasil perhitungan menunjukkan nilai signfikansi pemeriksaan dan tindakan perbaikan K3 sebesar $0,000<\operatorname{taraf}$ signifikansi $\alpha=0,05$, sehingga dapat disimpulkan bahwa pemeriksaan dan tindakan perbaikan $\mathrm{K} 3\left(\mathrm{X}_{4}\right)$ berpengaruh signifikan terhadap tindakan tidak aman. Hipotesis yang menyatakan bahwa pemeriksaan dan tindakan perbaikan K3 berpengaruh secara parsial terhadap tindakan tidak aman PT. Pelabuhan Penajam Banua Taka diterima.

\section{Pengaruh Dominan}

Diantara komitmen dan kebijakan $\mathrm{K} 3\left(\mathrm{X}_{1}\right)$, perencanaan $\mathrm{K} 3\left(\mathrm{X}_{2}\right)$, pelaksanaan $\mathrm{K} 3\left(\mathrm{X}_{3}\right)$, serta pemeriksaan dan tindakan perbaikan $\mathrm{K} 3\left(\mathrm{X}_{4}\right)$ yang mempunyai pengaruh paling dominan terhadap tindakan tidak aman adalah pemeriksaan dan tindakan perbaikan $\mathrm{K} 3\left(\mathrm{X}_{4}\right)$, hal ini karena nilai correlation partial yang berada pada tabel coefficients sebesar 75,3\% lebih besar dari nilai correlation partial variabel bebas lainnya. Sehingga dapat disimpulkan bahwa variabel pemeriksaan dan tindakan perbaikan $\mathrm{K} 3\left(\mathrm{X}_{4}\right)$ mempunyai pengaruh yang paling dominan terhadap variabel terikat tindakan tidak aman (Y).

\section{KESIMPULAN DAN SARAN}

Kesimpulan hasil penelitian ini adalah:

1. Berdasarkan hasil analisis diketahui bahwa terdapat pengaruh secara simultan antara variabel komitmen dan kebijakan $\mathrm{K} 3\left(\mathrm{X}_{1}\right)$, perencanaan $\mathrm{K} 3\left(\mathrm{X}_{2}\right)$, pelaksanaan $\mathrm{K} 3\left(\mathrm{X}_{3}\right)$, serta pemeriksaan dan tindakan perbaikan $\mathrm{K} 3\left(\mathrm{X}_{4}\right)$ terhadap tindakan tidak aman. Jadi hipotesis yang menyatakan bahwa variabel komitmen dan kebijakan K3, perencanaan K3, pelaksanaan K3, serta pemeriksaan dan tindakan perbaikan K3 secara simultan berpengaruh signifikan terhadap tindakan tidak aman diterima.

2. Dari hasil analisis diketahui bahwa terdapat pengaruh secara parsial antara variabel komitmen dan kebijakan $\mathrm{K} 3\left(\mathrm{X}_{1}\right)$, perencanaan $\mathrm{K} 3\left(\mathrm{X}_{2}\right)$, pelaksanaan $\mathrm{K} 3\left(\mathrm{X}_{3}\right)$, serta pemeriksaan dan tindakan perbaikan $\mathrm{K} 3\left(\mathrm{X}_{4}\right)$ terhadap tindakan tidak aman. Jadi hipotesis yang menyatakan bahwa variabel komitmen dan kebijakan $\mathrm{K} 3$, perencanaan $\mathrm{K} 3$, pelaksanaan $\mathrm{K} 3$, serta pemeriksaan dan tindakan perbaikan K3 secara parsial berpengaruh signifikan terhadap tindakan tidak aman diterima.

3. Dari hasil analisis diketahui bahwa pemeriksaan dan tindakan perbaikan $\mathrm{K} 3\left(\mathrm{X}_{4}\right)$ berpengaruh paling dominan terhadap tindakan tidak aman (Y). Jadi hipotesis yang menyatakan bahwa variabel pemeriksaan dan tindakan perbaikan K3 memiliki pengaruh dominan terhadap tindakan tidak aman diterima.

Adapun saran yang diberikan adalah: Karyawan wajib mentaati segala peraturan dan prosedur yang telah ditetapkan oleh perusahaan demi keselamatan karyawan dan nama baik perusahaan

1. Kepada pihak menajemen perusahaan khususnya P2K3 agar lebih meningkatkan pengawasan kepada karyawan agar tidak menimbulkan kecelakaan kerja yang serius pada akhirnya.

2. Menambah safety sign yang menunjukkan perintah untuk bertindak aman bagi pekerja.

\section{DAFTAR PUSTAKA}

Maslow, Abraham H. 2016. Motivation and Personality. New York: Harper \& Row Publisher.

Tafsir, Ahmad . 2016. Filsafat Umum (Akal dan Hati Sejak Thales Sampai Copra). Bandung: Rosda Karya.

Andi, Alifen, R \& Chandra, A. 2017. Model Persamaan Struktural Budaya Keselamatan Kerja Pada Perilaku Pekerja Di Proyek Konstruksi. Jurnal Tehnik Sipil, 12 (3).

S, Arikunto. 2016. Prosedur Penelitian Suatu Pendekatan Praktik. Jakarta.

Atkinson. 2015. Pengantar Psikologi Edisi Kesebelas Jilid 2. Jakarta: Interaksara.

Bodroastuti, Tri. 2015. Pengaruh Struktur Corporate Governanceterhadap Financial Distress, Jurnal Ilmu Ekonomi ASET, 11 (2).

Budiono, A., M., S. 2015. Bunga Rampai Higiene Perusahaan Ergonomi (HIPERKES) dan Kesehatan dan Keselamatan Kerja. Universitas Diponegoro: Semarang. 
Charehzehi, A., dan Ahankoob, A. 2012. Enhancement Of Safety Performance At Construction Site. International Journal of Advances in Engineering and Technology, 5 (1).

Christina, W. Y, Djahfar, L \& Thoyib, A. 2017. Pengaruh Budaya Keselamatan dan Kesehatan Keja (K3) terhadap Kinerja Proyek Konstruksi. Vol 6, No 1, ISSN 19785658.

Novianus, Cornelis. 2019. Hubungan Karakteristik, Ketersediaan Fasilitas dan Pengawasan dengan Tindakan Tidak Aman pada Petugas Penanganan Prasarana dan Sarana Umum di Jakarta Timur, Arsip Kesehatan Masyarakat, Vol 4 No 1 (2019), Universitas Muhammadiyah Prof. Dr. Hamka, Jakarta.

Dessy, Halinda dan Lina. 2014. Hubungan Penerapan Program Keselamatan Kerja Dengan Tindakan Tidak Aman Pada Karyawan PT Perkebunannusantara Iv Unit Bah Butong Kabupaten Simalungun Tahun 2013, Jurnal Kesehatan Lingkungan \& Keselamatan Kerja, 3 (3) (2014), Universirtas Sumatera Utara.

Gary, D. 2015. Manajemen Sumber Daya Manusia. Jakarta.

Ghozali, H. Imam. 2015. Aplikasi Analisis Multivariate dengan Progam SPSS. Badan Penerbit Universitas Diponegoro, Semarang.

Gibson, Ronald F., 2016. Principles of Composite Material Mechanics. NewYork: Mc Graw Hill,Inc.

Hersey, Paul \& Blanchard, K. 2015. Manajemen Perilaku Organisasi: Pendayagunaan Sumber Daya Manusia, Terjemahan Agus Dharma. Jakarta: Airlangga.

Hidayat, S., Suwandi, T., dan Qomarudin, M.B. 2015. The Analysis of Factors Related to Unsafe Acts on Welders in XYZ Ltd. International Journal of Advanced Engineering, Management and Science, 2 (6).

Ivancevich, J., M. 2016. Perilaku dan Manajemen Organisasi. Jakarta.

M, Manulang. 2016. Management Personalia. Jakarta: Ghalia Indonesia.

Mangkunegara, P., A. 2015. Sumber Daya Manusia Perusahaan. Bandung.

Mathis, R. L dan Jackson, J. H. 2015. Human Resource Managemen 9th ed., Sadeli, J. dan Hie, B.P (alih bahasa), Jakarta.

Neuman, W. Lawrence. 2015. Metodologi Penelitian Sosial Pendekatan Kualitatif dan Kuantitatif Edisi 7. Jakarta: Indeks.

Notoatmodjo, S. 2014. Pendidikan dan Perilaku Kesehatan. Jakarta: Rineka Cipta.

Nurmianto, E. 2015. Ergonomi Konsep Dasar dan Aplikasinya. Jakarta.

Pearce/Robinson. 2015. Manajemen Strategi (Formulasi, Implementasi, dan Pengendalian), Penerbit Salemba Empat, Jakarta.

Purnomo, H. D. 2010. Threshold IDF for feature selection in text classification, Just IT, Vol. 2, No.2.

Rahma dan Tjipto. 2019. Faktor Yang Berhubungan Dengan Tindakan Tidak Aman Pada Pekerja di Pabrik Pupuk NPK, Jurnal Kesehatan Masyarakat, 7 (1), Universitas Ibn Khaldun: Bogor.

Ramli, S. 2015. Sistem Manajemen Keselamatan Dan Kesehatan Kerja OHSAS 18001. Jakarta. Dian Rakyat.

H, Ranupandojo., dan Husnan, Suad. 2014. Manajemen Personalia, Edisi III, Yogyakarta: BPFE.

Rogers, L. 2014. Linguistic Orthogenesis : Scots Vowel Length and The English Length Conspiracy, Amsterdam: North Holland.

Santoso, Singgih. 2015. Statistik Parametrik, Cetakan Pertama, Penerbit Elex Media Komputindo, Jakarta.

Sastrohadiwiryo. 2015. Manajemen Tenaga Kerja Indonesia, Jakarta. 
Silalahi, B. N.B. dan Silalahi, R. 2015. Manajemen Keselamatan Dan Kesehatan Kerja. Jakarta: Bina Rupa Aksara.

Simanjuntak. 2015. Manajemen Dan Evaluasi Kinerja. Jakarta: Fakultas Ekonomi Universitas Indonesia.

Sugiyono. 2015. Metode Penelitian Bisnis. Alpabeta, Bandung.

Sulaksmono, M. 2016. Manajemen Keselamatan Kerja.Surabaya: Penerbit Pustaka.

Suma'mur, PK. 2015. Keselamatan Kerja Dan Pencegahan Kecelakaan. Jakarta: Haji Masagung.

Tarwaka, Sholichul, Lilik Sudiajeng. 2014. Ergonomi Untuk Keselamatan, Kesehatan Kerja dan Produktivitas, Surakarta: UNIBA PRESS.

Trijoko, Prasatya. 2014. Ilmu Budaya Dasar. Jakarta: Renika.

Wignjosoebroto, S. 2016. Ergonomi Studi Gerak dan Waktu. Surabaya.

Winarsunu, T., 2016. Psikologi Keselamatan Kerja. Malang: UMM Press.

No 2, 20-32 